\title{
Dendritic Cells in Systemic Lupus Erythematosus
}

\author{
Heather M. Seitz ${ }^{1}$ and Glenn K. Matsushima ${ }^{2,}{ }^{*}$ \\ 1Johnson County Community College, Science Division, 12345 College Blvd. Overland Park, KS \\ 66210 \\ ${ }^{2}$ UNC Neuroscience Center, Department of Microbiology \& Immunology, Program for Molecular \\ Biology \& Biotechnology, University of North Carolina-CH, Chapel Hill, NC 27599
}

\begin{abstract}
Systemic lupus erythematosus (SLE) persists as a chronic inflammatory autoimmune disease and is characterized by the production of autoantibodies and immune complexes that affects multiple organs. The underlying mechanism that triggers and sustain disease are complex and involves certain susceptibility genes and environmental factors. There have been several immune mediators linked to SLE including cytokines and chemokines that have been reviewed elsewhere(1-3). A number of articles have reviewed the role of B cells and T cells in SLE(4-10). Here, we focus on role of dendritic cells (DC) and innate immune factors that may regulate autoreactive B cells.
\end{abstract}

\section{Types of DC}

DC are a heterogeneous group of bone marrow-derived cells that function in immunosurveillance, antigen-presention and tolerance. DC subtypes may be dictated by anatomical location or methodologies in culture conditions. This may partly explain some differences in human DC and mouse DC phenotypes. The general categories of DCs are the conventional dendritic cells (cDC) and the plasmacytoid dendritic cells (pDC). The cDC include those found in the skin, in secondary lymph nodes and the spleen. They are subdivided into two categories, migratory DCs and resident DC. These subsets of DCs have distinct phenotypes summarized in Table 1.They also reside in mucosal tissues and these DCs have been discussed elsewhere $(11,12)$. In the skin, there are DCs which may become Langerhans cells; however, there are other cDC that are derived from monocytes during inflammation(1, 13). These DCs are migratory and upon antigen acquisition, they move to secondary lymph nodes and the spleen. This migration of DCs involves a complex sequence of molecular signals dictated by surface receptors, chemokines, cytokines and microenvironments that guide DCs to proper areas to activate lymphocytes $(1)$. In addition, the $\mathrm{CD} 8 \mathrm{a}^{-}, \mathrm{CD} 4{ }^{+} \mathrm{CD} 11 \mathrm{~b}^{+} \mathrm{DCs}$ localize mostly to the marginal zone and express DCIR2 that presumably targets antigen to the endocytic pathway and onto MHC class II, thereby activating $\mathrm{CD}^{+}{ }^{+} \mathrm{T}$ cells. These $\mathrm{CD} 8^{-} \mathrm{DCs}$ also express the inhibitory molecule SIRP $\alpha$ which in Langerhan cells controls migration and they express CD47 which appears to be important for their development $(14,15)$.

Among the cDCs found in the spleen, they are identified by several cell surface markers including $\mathrm{CD} 11 \mathrm{c}^{\mathrm{hi}}, \mathrm{CD}^{+}, \mathrm{CD} 205^{+}$, and $\mathrm{MHC} \mathrm{II}{ }^{+}$. Human DCs do not express $\mathrm{CD} 8$ or DEC-205 and murine cDCs are alsoCD $8 \alpha^{-}, \mathrm{CD} 205^{-}(16,17)$. Moreover, the CD $8 \alpha^{+}$DCs have been further distinguished based on their lack of expression of the CD4 marker. These

*Corresponding author: Glenn K. Matsushima, Ph.D., UNC Neuroscience Center, CB\#7250, University of North Carolina-CH, Chapel Hill, NC 27599, TEL: (919) 966-0408.

Declaration of interest: The authors report no conflicts of interest. The authors alone are responsible for the content and writing of the paper. 
$\mathrm{CD}^{+} \mathrm{a}^{+}, \mathrm{CD} 4^{-} \mathrm{DCs}$ reside primarily in the $\mathrm{T}$ cell zones and are thought to be more phagocytic and have a greater capacity for direct presentation and crosspresentation to $\mathrm{T}$ cells(17-24).

\section{Conventional DC}

$\mathrm{cDC}$ are derived from monocytic lineage and reside primarily in epithelial tissues such as the skin and in different mucosal organs. cDC at these key positions in various tissue allow for the immunosurveillance against potential invading pathogens. The two main functions of these DCs are to induce specific adaptive immune responses to pathogens and to maintain selftolerance. This immunosurveillance places DCs at the interface of innate immunity and adaptive immunity.

One of the most studied cDC is the skin DCs and this also includes DCs known as Langerhans cells. Upon exposure to pathogens or insult, immature DC can recognize foreign material and phagocytize them. This phagocytosis is not as efficient as professional phagocytes such as macrophages; however, the main function of DCs carrying antigenic cargo is to migrate to secondary lymph nodes to activate $\mathrm{T}$ cells, particularly naïve $\mathrm{T}$ cells. This migration of $\mathrm{DC}$ and the molecular traffic signals are covered in a recent review(1). These DCs are positive for the lectin langerin and they express high levels of MHC class II molecules(16,25). In mice, langerin is expressed at low levels on CD8 ${ }^{+} \mathrm{CDs}$ in lymphoid organs and on a subset of DCs in the lungs.

The $\mathrm{CD} 8^{+}$lymphoid cDCs as well as B cells are thought to be important in maintaining self tolerance or specific immune response to pathogens. However, lupus pathogenesis is thought to arise from these APCs possibly through abnormal antigen-processing or inappropriate presentation causing excessive stimulation of autoreactive T cells. Autoreactive T cells to nuclear antigens such as DNA and histones or small ribonucleoproteins including Smith (Sm) antigens, $\mathrm{U} 1$ and heterogeneous ribonucleoprotein (hnRNP) A2 have been associated with SLE (26-30). These autoreactive T cells may provide help to B cells and promote the activation of autoreactive B cells from anergy(6). However, many studies on T and B cell tolerance use model systems that may apply to normal B cells and not necessarily autoreactive B cell that may have other requirements for anergy or activation(10). Interestingly, recent studies have focused a $\mathrm{T}$ cell-independent induction and regulation of autoreactive B cells.

\section{Plasmacytoid DCs}

pDCs have the prominent feature of producing type I interferon (IFN I)(31-33). The typical phenotype of human $\mathrm{pDC}$ is shown in Table 1 and this is somewhat in contrast to the murine pDC (34-39). Both pDC upregulate MHC II and costimulatory molecules and can activate T cells(40). These pDC appear to be geared towards immunity against viruses and bacteria because they express primarily TLR7 and TLR9 which senses components of RNA complexes and DNA (particularly CpG sequences) respectively in endosomal compartments(41-46). However, pDC do not express TLR2, TLR3, TLR4, or TLR5. pDC are low in numbers in the blood of SLE patients; however, the large amounts of IFN I in lupus is attributed to activated pDC in the lymph nodes, skin or target organs(47-50). This copious production of IFN I is triggered by the formation of nucleic acid bound to antibodies (immune complex) which are internalized via Fc $\gamma$ RIIa into endosomes. Subsequently, the nucleic acids are detected by TLR7 or TLR9 within the endosomal compartment and results in pDC activation and IFN I secretion (Figure 1). In addition, one negative signaling pathway utilizes CD303, C-type lectin, and FcR $\gamma$-chain to inhibit transcription of IFN-I and IFN-I responsive genes in human pDCs(51).

In comparing TLR9 function of $\mathrm{pDC}$ versus $\mathrm{CDC}$, TLR9 is critical for the activation and survival of $\mathrm{pDCs}$ whereas it appears dispensible for activation of $\mathrm{cDC}(52)$. Using a TLR9 ligand, CpG DNA-stimulated pDCs deficient in NFkB1 and C-Rel produced IFN I but not IL-6 
or IL-12 and underwent apoptosis(52). This finding was consistent with reports that TLR9deficient, Fas-deficient, lupus-prone mice were inhibited in anti-dsDNA and anti-chromatin autoantibody production(53). However, anti-Sm antigen antibody (a marker of SLE) was maintained or increased in TLR9 ${ }^{-1-}$ mice. It is likely that TLR7, a receptor for the ribonucleoprotein $\mathrm{Sm}$ antigen, is functionally intact in $\mathrm{TLR} 9^{--}$mice and can respond by producing antibody to the $\mathrm{Sm}$ autoantigen. Despite the reduction in anti-dsDNA antibody, $\mathrm{TLR}^{-1-}$ lupus-prone mice maintained a hyperimmune phenotype and autoimmune pathologies. Contrary to these finding in $\mathrm{TLR}^{-/-}$lupus-prone mice, $\mathrm{TLR} 7^{-/-}$lupus-prone mice showed decreased lymphocyte and pDC activation, decreased serum IgG and ameliorated autoimmune disease(54). Thus, TLR7 and TLR9 appear to have different roles in the development of murine lupus and these studies suggest autoantibody production dependent on TLR7 may have a greater impact on disease. Subsequent to these studies of TLR9, a second group suggested the absence of TLR9 on the MRL/lpr background exacerbated autoantibody production and pathology; thus, TLR9 is not required for pathogenesis and it appears to provide protection(55). The difference in results could be due to the greater number of backcrosses onto the MRL/lpr background; hence, a greater number of disease susceptibility loci would be operating(55). These two studies suggest TLR9 may provide protection versus exacerbation of autoimmune disease depending on the genetic background of the lupus-prone mice. Nonetheless, when pDC become activated, they are known to express the chemokine receptor, CXCR3, which directs them to sites of inflamed lymph nodes(56-58). It is interesting that some autoreactive B cells from SLE patients also express CXCR3 and may also home to sites of inflammation(59).

When considering the activation of $\mathrm{pDC}$, the same stimulants must be considered in the context of B cell activation as well. From SLE patients, a large proportion of B cells expressing TLR9 correlated with high anti-DNA autoantibodies(60). In murine B cells, subsequent TLR9-

MyD88-dependent signaling is critical for class switching to pathogenic IgG antibodies. (61) The absence of TLR7 or TLR9 or the simultaneous blocking of TLR7 and TLR9 signaling in B cells inhibited the development of autoantibodies $(54,61,62)$. Thus, at least in B cells, TLR7 and TLR9 along with the BCR signaling appear to activate B cells and promote autoimmunity.

\section{Follicular DCs}

A separate category of cells known as follicular dendritic cells (FDC) reside primarily in germinal centers of secondary lymphoid tissues and function to trap antigen for B cell stimulation $(63,64)$. FDC have a number of varying cell surface markers that are partly shown in Table 1 and they retain immune complexes holding antigens using Fc $\gamma$ receptors or complement receptors and facilitate the selection of high affinity antibodies; although, high affinity maturation can occur in the absence of detectable immune complexes on FDCs(6567). Recent imaging using two-photo microscopy demonstrated FDC that acquired labeled hen egg lysozyme (HEL) antigen engage cognate B cells for an average of 3 minutes(68). These $\mathrm{B}$ cells possessed BP- $3^{+}$fragments of FDCs on their surface indicating the likelihood of antigen capture. In addition, FDC have protected B cells in germinal centers from apoptosis by the provision of Notch ligands and BAFF to promote B cell survival(69). Whether FDC acquire self-antigens and engage autoreactive $B$ cells in this manner is not clear; however, the presence of apoptotic material has been detected on the surface of FDCs in a subgroup of patients with SLE(70). Consistent with this concept, a recent report suggests FDC are essential for induction of autoantibody in a model of arthritis(71). Moreover, MFG-E8-secreting FDC have recently been shown to be critical for the removal of apoptotic cells (AC) by tingible-body macrophages that are in close proximity(72). Defects in clearing dying B cells may provide an environment conducive to ample autoantigens (See Figure 1). In biopsied samples from case studies of SLE lymphodenopathy, a number of patients exhibited a disarray of their FDC network suggesting FDC may be related to disease induction(73). 


\section{Phagocytosis by DC and SLE}

One feature found in many patients with SLE is the presence of dying cells in lymph nodes and various tissues $(70,74)$. This manifestation is a result of either cells dying more frequently or an inability to clear the AC. It is plausible that during injury, oxidative stress or infection by pathogens, the abundance of dying cells may be overwhelming and exposure to large doses of autoantigen may break tolerance. On the other hand, an inability to ingest even normal daily turnover of cells may render one susceptible to autoimmune responses. Cells dying by apoptosis provide efficient notification of their impending death by expression of inner plasma membrane molecules such as phosphatidylserine (PS) which become inverted onto the outer membrane (75). Furthermore, cells undergoing apoptosis release lysophosphatidylcholine or other factors which attracts phagocytes to dying cells $(76,77)$. Proper clearance of apoptotic cells is thought to prevent exposure of self antigens and inhibit the activation of immune cells. In contrast, primary necrotic cells release different chemical signals such as the nuclear DNA-binding protein, high mobility group box 1 protein (HMGB1), hyaluronic acid, uric acids which attract phagocytes and trigger inflammation $(78,79)$. Therefore, the defects in engulfment of ACs in some SLE patients and in lupus-prone animals suggest more self antigens are available for DCs to activate autoreactive B cells.

Upon engagement with PS on ACs, several receptors on phagocytes trigger recognition and engulfment(75). This engulfment of cells in the early stages of apoptosis activates the phagocyte to secrete IL-10 and TGF- $\beta$ which promote an anti-inflammatory state $(75,80)$. In fact, it has recently been shown that ACs administered to mice prevented endotoxic shock by binding to LPS, reducing proinflammatory cytokines and by suppressing neutrophil infiltration into target organs; however, a majority of studies on immune modulation by AC have been on macrophages(81). Interestingly, an emerging area is the role of AC in shaping DC function in cancer and SLE.

It is apparent that clearing ACs is important so that cytosolic and nuclear self-components of dying cells are prevented from being released into the interstitial compartments to sensitize autoreactive T or B cells. Furthermore, proinflammatory cytokines produced by DCs such as IL-1, IL-12 and TNF- $\alpha$ are actively inhibited by exposure to AC(82-84). However, if ACs are not adequately cleared, dying cells enter late stage apoptosis or a secondary necrosis stage which releases not only nucleosomes, snRNPs, and DNA, but also exposure of HMGB1nucleosome complexes and other signals to trigger inflammation(85-87). Earlier evidence suggested HMGB1 was released by primary necrotic cells and induced inflammation whereas ACs undergoing secondary necrosis bound HMGB1 tightly to chromatin and did not trigger inflammation(88). However, HMGB1 has been implicated in SLE and more recently, an alternative mechanism has been proposed for immune activation by HMGB 1 from secondary necrotic cells. HMGB1 from secondary necrotic cells requires binding to nucleosomes to induce activation of DCs and macrophages which results in the secretion of proinflammatory cytokines and autoantibodies(87). Free HMGB1 from viable cells or nucleosomes without HMGB1 were not able to activate DCs or induce cytokine production. This HMGB1nucleosome response was mediated by TLR2 but not TLR4, TLR9 or RAGE even though HMGB1 can bind TLR4 and RAGE(87). One additional note, DCs from SLE patients that were defective in engulfment of ACs were also poor at regulating IL-12 producing three-fold more than normal controls, had higher levels of CD86 and were poor at generating tolerizing DCs(89). Interestingly, HMGB1 was shown to bind to PS and prevent phagocytosis of apoptotic neutrophils(90). It is plausible that HMGB1 in SLE patients may be binding to PS on ACs thereby preventing adequate engulfment and inhibition of DCs or other phagocytes (90). 
Several studies have identified multiple receptors that regulate ingestion of ACs by macrophages; however, there are fewer reports for mechanisms that are employed by DCs. $\mathrm{CD} 8^{+} \mathrm{CD} 11 \mathrm{c}^{+} \mathrm{DC}$ phagocytize debris more efficiently and are the cells responsible for ingestion of $\mathrm{AC}$ whereas $\mathrm{CD} 8^{-} \mathrm{CD} 11 \mathrm{c}^{+} \mathrm{DC}$ do not phagocytize $\mathrm{AC}(91,92)$. The ingestion of ACs by CD8 ${ }^{+}$DC is facilitated by their expression of DEC205 and CD36 and DC, NK lectin group receptor-1 (DNGR-1)(91-93). One of the earlier described ligand that bound apoptotic cells was $\mathrm{Clq}$ and it is produced by macrophages and $\mathrm{DCs}(94)$. C1q can directly opsonize ACs and it is recognized by calreticulin or CD91 on phagocytes(95). C1q is thought to suppress DC activity and the lack of $\mathrm{C} 1 \mathrm{q}$ or other complement components results in autoantibody formation in humans and murine models(96). Furthermore, other receptors that trigger ingestion of ACs have been shown to be different for DC versus macrophages(97). Macrophages rely predominantly on Mertk, a cell surface receptor tyrosine kinase; in contrast, DCs do not utilize Mertk but rather involve other family receptors, Axl and Tyro3(97,98). The use of Axl and Tyro3 as phagocytic receptors for the ingestion of ACs is much slower taking nearly 6 hours whereas macrophages engulf dying cells within 15-30 minutes(97). The impact of the delayed uptake of ACs by DCs is not fully known; however, despite not being used as a phagocytic receptor, Mertk appears to influence DC deactivation including downregulating IL-12 when exposed to ACs (See Figure 1)(82,83). This illustrates the complexity of receptors engaged in clearing ACs and the multiple signaling consequences that regulate subsequent immune responses. It is plausible that defects in the downstream Mertk-signaling pathways may be occurring in some patients with SLE.

The phagocytosis mediated by Mertk on macrophages appears to involve phosphorylation of vav1 or av $\beta 5$ integrin to induce actin rearrangement $(99,100)$. In transfected cell lines, Mertk associates with integrin $\alpha v \beta 5$ which recruits FAK and facilitate phagocytosis by activating Rac1; however, it is not known whether a similar association is absent in DCs and accounts for the lack of function of Mertk as a phagocytic receptor(99). Complementarily, the $\alpha v \beta 5$ ligand, MFG-E8, also recognizes PS and tingible-body macrophages are responsible for removal of excess B cells in germinal centers (See Figure 1)(101,102). In $m f g-e 8^{-/-}$mice, lack of removal of apoptotic $\mathrm{B}$ cells in the germinal centers resulted in autoantibody production $(101,103,104)$. Interestingly, FDC are the critical producers of MFG-E8 which provide tingible-body macrophages the bridging ligand to ingest dying B cells. Consistent with this finding, $L \mathrm{Ta}^{-1-}$ mice that lack FDC also lack MFG-E8 and suffer from autoimmunity(72). These experimental observations may correlate with reduced phagocytosis of ACs by tingiblebody macrophages from SLE patients(70,74). It is not clear whether Axl and Tyro3 used by

DC interact with integrins to modulate phagocytosis; however, these receptors appear critical for TLR regulation and cytokine suppression using a negative feedback loop initiated by AxlIFNR-I(105). Lastly, scavenger receptor A (SRA) blockade has shown dramatic inhibition of phagocytosis of ACs by macrophages. It was later demonstrated that SRA associates with Mertk to signal ingestion(106). Without SRA, engulfment by $60 \mathrm{~min}$ is only delayed and not abrogated. This suggests engulfment is similar to wild type macrophage and that other molecules are likely activating Mertk. It is not clear whether SRA is important for DC phagocytosis.

Mice deficient in this family of Mertk, Axl and Tyro3 receptors result in autoantibody presumably due to their inability to adequately clear $\operatorname{ACs}(107-109)$; however, our recent data suggest Mertk may be the critical receptor responsible for the autoimmune phenotype since induction of ACs were adequately cleared in wild type, $a x l^{-1-}$ or tyro $3^{-/-}$mice but not mertk ${ }^{-/-}$mice(97). Furthermore, the induction of Mertk expression upon binding of ACs is dependent upon a transcription factor, liver X receptor (LXR)(110). Mice deficient in LXRsignaling possessed macrophages incompetent in the engulfment of ACs, produced autoantibodies and displayed autoimmune phenotype. This is very similar to Mertk-deficient mice $(107,109)$. The role of LXR in DCs was not examined but LXR agonists did not affect 
expression of Axl or Tyro3. Thus, the regulation of Mertk is separate from Axl and Tyro3 and may suggest possible functional differences in DCs also.

ACs expressing PS are bound by several ligands including GAS6 or protein S. In addition to being critical for blood coagulation cascades, these factors act as a molecular bridge to bind Axl and Tyro 3 on DCs or Mertk on macrophages to initiate phagocytosis. GAS6 can bind all three receptors having greater affinity for Axl and less for Tyro3 or Mertk(111). Interestingly, GAS6-deficient mice do not show obvious autoimmunity suggesting it is not an essential factor and that other bridging molecules such as MFG-E8 may be more important given it is a ligand for $\alpha \mathrm{v} \beta 5$ and appears to work in conjunction with Mertk to facilitate phagocytosis of ACs $(99,104,112)$. In contrast, deletion of protein S results in embryonic lethality (E17.5) in mice and the precise role in autoimmunity has not been determined; however, protein $\mathrm{S}$ is important for phagocytosis of ACs and low expression of protein $\mathrm{S}$ or anti-protein $\mathrm{S}$ antibodies have been detected in patients with SLE(102,113-115). Early reports for protein S have been confusing in studies using reagents from different species. Protein $S$ was found to engage Tyro3 and it does not bind Axl nor Mertk; however, a recent report suggest auto-oxidation of cysteine residue in protein $\mathrm{S}$ results in dimerization and this is a prerequisite for binding to Mertk on human macrophages $(116,117)$. In contrast to findings in murine macrophages which expressed all TAM family members, the human macrophages expressed only Mertk. In that study, DCs were not examined; however, murine DCs apparently do not require Mertk for engulfment of ACs, utilize Axl and Tyro3 to engulf ACs and produce protein S but not GAS6 $(97,98)$. As part of this model for DC engulfment of ACs, GAS6 is produced by dying thymocytes but they do not produce protein $\mathrm{S}(83)$. If Axl recognizes GAS6 but not protein $\mathrm{S}$ and Tyro3 binds protein $S$ but with less affinity to GAS6, then it is plausible that GAS6 provided by ACs could facilitate interaction with Axl and complement DC-derived protein S to bind Tyro3 to engulf ACs. Further experimentation will be necessary to corroborate the interaction of DCs with ACs.

The receptors involved in AC engulfment not only drive autoimmunity, but, the interaction of DCs with ACs or their intermediate ligands has consequences on DC maturation and function. PS inhibited the upregulation of HLA molecules on human DCs, inhibited secretion of IL-12, and reduced their ability to stimulate $\mathrm{T}$ cells(84). A number of receptors may be participating in the recognition and engulfment; however, it is not clear which combination may be regulating maturation and cytokine suppression. CD36 and $\alpha v \beta 3$ are known to participate in macrophage engulfment of ACs but not in the regulation of cytokine secretion(118). Also, $\mathrm{CD} 36$, $\alpha \mathrm{v} \beta 3$, or $\alpha \mathrm{v} \beta 5$ integrins highly expressed on $\mathrm{CD} 8^{+} \mathrm{DCs}$ does not influence cross presentation or cross tolerance $(92,119)$. However, cross-linking of CD36 has been shown to suppress human DC activation of T cells and induce the secretion of IL-10. In the murine system, Mertk has been implicated as a major regulator of NFkB in DCs and inhibitor of IL-12 (82). In addition, expansion of DC populations may contribute to autoimmunity. LAG3 was originally described in regulating lymphocyte expansion; however, it has been recently found on pDC but was not expressed on cDCs(120). The function of LAG3 on pDCs appears to be in the regulation of proliferation and expansion but does not affect maturation markers.

\section{Role of Type I Interferon}

There is an association of IFNI found in the serum of patients with $\operatorname{SLE}(79,121)$. Further link for a role of IFNI was made from observations of patients receiving IFN treatment for viral infection or tumor therapy $(122,123)$. A fraction of these patients had detectable autoantibodies and a few developed autoimmune symptoms. In addition, reviews on IFNI suggest it has powerful roles in shaping immune responses in SLE by affecting lymphocyte, macrophage, DC and NK activation $(124,125)$. Thus, understanding the critical signaling pathways that lead to a break in tolerance and autoimmunity may be difficult given the pleotrophic affects of IFNI. 
TLR ligands that recognize CpG DNA (TLR9), RNA (TLR6 \& TLR7) are often associated with human pDCs. When macrophages are activated by TLR ligands, IFNI is upregulated either in an autocrine or paracrine manner. Interestingly, IFNI has been shown to induce the expression of Axl in macrophages(126). In DCs, TLR4 stimulation upregulates IFNI and a complex of Axl and IFNR-I(105). Axl-IFNR-I complex bind IFNI and induces Stat-1 which subsequently activates suppressor of cytokines (SOCS) genes, SOCS-1 and SOCS-3(105, 126). The SOCS proteins in turn, associate with various intracellular signaling molecules to inhibit TLR-mediated activation of DCs(127). Furthermore, Axl activation after binding to GAS6 has been shown to be a chemotactic and survival signal for human DCs(128). This suggests that IFNI and Axl signal transduction pathways may have multiple functions including the regulation of DC immune responses. Because several self-DNA, RNA and nucleic acids from pathogens can trigger various TLR signaling, it is thought infectious agents or endogenous nucleic acids may be one environmental cue that triggers SLE.

A second important mechanism for the activation of DC is by immune complexes (IC) formed by autoreactive antibodies and nuclear components $(129,130)$. These IC are captured by pDC as mentioned above and upon Fc receptor-mediated internalization, TLRs activate the pDC to secrete IFNI. Furthermore, IC can also be captured by FDCs and may be a source of autoantigens for naïve autoreactive $\mathrm{B}$ cells. If autoreactive $\mathrm{B}$ cells die after not receiving survival signals, FDCs secrete MFG-E8 which aids in phagocytosis of ACs by nearby tingiblebody macrophages(72). Thus, pDC, FDC and macrophages cooperate in an intimate relationship to rid germinal centers of ACs.

Key experiments have shown IFNI is important in the development of autoantibody production (131-133). In different murine models of SLE, deletion of the IFNR-I results in diminished autoantibody titers and disease(124,134-136). Several cytokines, chemokines and upregulation of various receptors on B cells, T cells and innate immune cells have been associated with models of lupus. It is not clear which population of DC is pivotal in regulating the autoimmune phenotype; however, IFNI responsive genes offer clues. Several labs have embarked on studies using microarrays and proteomics to identify downstream genes that may be associated with the development of lupus. Recently, nearly half the SLE patients were found to have upregulated IFN responsive genes in peripheral blood mononuclear cells(137). Consistent with the important link of IFNI, TYK2 and IRF5 were pulled from SNP analysis in a population of patients with SLE $(138,139)$. TYK2 associates with the IFNRI and with JAK1 to initiate STAT activation(140). In addition, IRF5 is found in B cells and DCs, and IRF5 is activated by certain TLRs to induce IFNI(141). Thus, these polymorphisms appear to have a logical link for a role of IFNI in the pathogenesis of SLE.

The high levels of serum IFNI has been associated with SLE(48,130,142-144). The high levels of IFN has been correlated with increase activation of T cells by DCs(145). The trigger for IFNI secretion by pDC can be IgG-opsonized ACs mediated through Fc $\gamma$ RIIa, ICs containing anti-dsDNA antibodies bound with DNA, ICs containing RNA bound antibodies, or DNA derived from ACs, implicating autoantibodies in IFNI production $(129,146,147)$. This secretion of IFNI along with IL- 6 and CD 40 has been shown to induce B cells differentiation into plasma cells; however, B cells may also differentiate in the absence of CD40 ligation(148,149). More recently, apoptotic blebs rather than $\mathrm{ACs}$ were ingested readily and stimulated $\mathrm{pDC}$ to mature by increasing CD86 and CD40 expression along with production of IL-6 and TNF $\alpha(150)$. In addition, IFNI can promote class isotype switching by stimulating DCs(151).

\section{Interferon and TLRs}

It has been speculated that SLE symptoms are exacerbated by infection-induced or UV-induced apoptotic cells and this may trigger IFNI production, particularly in cutaneous lupus 
erythematosus $(47,61,152)$. Nucleic acid exposure is thought to activate DCs, macrophages and B cells. A body of evidence includes TLR3, TLR7, TLR9 as important receptors for the activation of innate immune cells and the secretion of IFNs $(153,154)$. Furthermore, a greater proportion of B cells and monocytes from SLE patients have been shown to express TLR9 (60). In addition, one recent report indicates TLR4 activation requires IRF7 and partly IRF5 signaling, and this results in IFN $\alpha$ production whereas IFN $\beta$ IRF3 in murine $\mathrm{CDC}$ and human monocytes $(155,156)$. Thus, it is plausible that bacterial infections may trigger acute symptoms in SLE; however, it is not clear why IFNI would then result in flares(155). Interestingly, IRF5 has been associated with SLE whereas IRF4 may be protective by competing for IRF5 in TLR signaling. In a similar protective manner, lower expression of IRF3 due to a polymorphism in the promoter suggests lower risk of SLE(157). Experimentally, the role of TLRs in autoimmunity have been extensively studied and reviewed elsewhere(6). Lastly, IRAK1 is a TLR downstream signal intermediate and is a risk gene for SLE $(153,158)$. IRAK1 has been associated with sle 1 or sle 3 disease loci and sle3 possess hyperactive DCs that manifests in increased T cells activity(159). Mating of IRAK1-deficient mice with B6.sle3 mice reduced CD80 expression on DCs and reduced TNF $\alpha$ production to TLR3 and TLR9 agonists(158). It is thought that the lack of IRAK1 inhibited the DCs and resulted in diminished autoantibody production. Therefore, several TLR-signaling factors may prompt or control the induction of SLE and adds to the difficulty in predicting individuals prone to developing SLE.

\section{Interferon and HIN 200 Family}

Though several mechanisms can induce IFNI and promote SLE, the molecular pathways are only partly understood. One important link to the IFN pathway is the discovery of the HIN200 family of IFN-inducible genes(160). This gene cluster have been associated with autoimmuneprone mice(161). One in particular has come to the forefront, p202 (IFI202)(162). In the NZB and $(\mathrm{NZB} \times \mathrm{NZW}) \mathrm{F} 1$ mice, multiple genes contribute to the autoimmune phenotype $(163,164)$. A prominent locus from backcrossed mice termed $\mathrm{Nba} 2$ is associated with autoantibody production. Expression profiling found p202 and p203 in the Nba2 interval of B6 congenic mice; however, only p202 was highly expressed in B cells and nonlymphocytes(162). Furthermore, p204 was not highly expressed in spleen cells from B6.Nba2 mice and it was found that p202 was expressed in NZB parent mice but not NZW or nonautoimmune B6 splenic cells. This suggested that p202 gene may be linked to autoreactive B cells and may be involved in breaking tolerance checkpoints in B cell maturation and survival $(6,9,160,165)$. Interestingly, we have found p202 expression in DCs and macrophages (unpublished data) and this suggest that antigen-presenting cells may be affected by p202. Moreover, another HIN200 family member, AIM2, has been associated with caspase-dependent cytoplasmic DNA-mediated macrophage death and p202 has been recently shown to counter this cell death(166-169). DCs may have a similar mechanism to deal with self-DNA and pathogen-associated DNA but under aberrant conditions of SLE, this form of self-limitation of infections may be defective. Thus, hyper-activated DCs that over-express p202 could survive longer than necessary and they may result in prolonged engagement with autoreactive $B$ cells which may contribute to autoimmunity. Indeed, defects in DC apoptosis in mice deficient in BIM or mice specifically deleted of Fas or a caspase inhibitor p35 in DCs, developed autoimmunity presumably due to DC accumulation, hyperactivation of lymphocytes and autoantibody production(170-172). Interestingly, a contrary report suggested engagement of FAS on DC actually causes the induction of chemokines and they become activated to survive rather than die(173). In fact, Axl/IFNR has been implicated in the chemotaxis and survival of human DCs and this may have implications in SLE patients that are characterized by high levels of IFNI(128). IFNI stimulation increased Axl expression on immature DCs and in the presence of the Axl ligand, GAS6, these DCs were rescued from growth factor deprivation-induced apoptosis.

Furthermore, GAS6 pretreatment of differentiating DCs prevented LPS responses and inhibited the production of cytokines. This may be linked to earlier observations that PS also inhibited 
human DC maturation and reduced T cell stimulation(84). It is plausible that exposure to ACs may allow survival of these DCs and increase a likelihood of stimulating autoreactive B cells. It is possible too that ACs may inhibit DC maturation and they therefore can't activate T regulatory cells or repress autoreactive $\mathrm{T}$ cells. Thus, defects in clearing ACs may lead to a lack of DC inhibition and maturation which may result in overactive immature DCs that can't activate regulatory $\mathrm{T}$ cells nor repress autoreactive $\mathrm{B}$ cells.

\section{DC regulating $B$ cells}

DCs activate naïve T cells extraordinarily well due to their high surface expression of MHC and costimulatory molecules. However, evidence suggests that T-independent activation of autoreactive B cells may occur in extrafollicular areas of the spleen(6). DC may interact with low affinity autoreactive B cells that may be regulated by different principles. There are ample reports regarding the DCs maintaining central and peripheral $\mathrm{T}$ cell tolerance but alternative mechanisms must be operating to explain circumstances involving T-independent autoreactive B cells $(4,174-178)$. We mentioned above how pDCs or FDCs may contribute to the induction of autoantibodies. In addition, DCs and macrophages may activate naïve B cells by providing IFNI, IL-6 and BAFF $(179,180)$. In contrast, recent studies suggested TLR-stimulated macrophages and DCs imparted regulatory activities on autoreactive B cells $(181,182)$. These reports suggested that DCs and macrophages release IL-6 and sCD40L locally which inhibited antibody production from autoreactive follicular B cells. This suppressive affect by DC (and macrophages) required close proximity to the autoreactive follicular B cells; however, this suppression is temporary as removal of these secreted ligands reversed the inhibition. Interestingly, marginal zone (MZ) B cells were only inhibited by sCD40L from macrophages. Thus, autoreactive B cells chronically exposed to antigen behave differently that conventional B cells and may respond to IL-6 through reprogramming of intracellular signaling mechanisms (10). This repressive effect by DC required B cells to be chronically stimulated with antigen. Coincidentally, DCs and macrophages have been shown to possess autoantigens on their cell surface presumably from apoptotic or necrotic cells. These DCs could be providing nearby autoreactive B cells with a source of self antigen and suppressive factors to impose a state of anergy. Furthermore, whether autoreactive B cells are repressed may depend on their anatomical location in lymphoid tissues(7). MZ B cells may be repressed by SCD40L secreted by MZ macrophages but when activated, the B cells may move to periarteriolar lymphoid sheaths (PALS) where they encounter DCs and become repressed by IL-6(182). In autoimmune-prone MRL/lpr mice, DCs and macrophages cannot repress autoreactive B cells due to defects in IL-6/sCD40L secretion(183). Thus, TLR-activated DCs appear to regulate B cells not only through $\mathrm{T}$ cell-mediated regulatory mechanisms, but they may impact autoreactive B cells directly by their provision of antigen and secretion of IL-6 and SCD40L. Whether this model of DC/macrophage-induced tolerance of autoreactive B cells occurs in certain patients with SLE remains to be examined.

\section{Summary}

DCs subtypes have individual functions and appear to influence multiple processes that may activate or repress autoreactive B cells. Part of their influence is dictated by their receptor and cytokine profiles and by their location. The checkpoints for regulating autoreactive B cells which may be different than conventional B cells may be due to changes in activation threshold, the hyperimmune phenotype under IFNI stimulation, or their response to negative regulators such as repression by TNF $\alpha$, IL- 6 and SCD40L which can be produced by properly activated DCs or macrophages. The observation that an abundance of IFNI in SLE patients and work in murine models suggest IFN-responsive genes may play a significant role in the development of SLE. From studies of lupus-prone mice, it appears that multiple points that regulate autoreactive B cells are defective allowing for the maturation of autoreactive B cells. In 
addition, the potential of DCs surviving longer may disrupt normal engagement of autoreactive B cells, thus skewing B cells towards antigen- activation of autoreactive B cells rather than repressing them. Although the characterization of DC and affect on B cells have contributed greatly to our understanding of tolerance, further studies involving DCs from lupus-prone models and autoreactive B cells may provide new insights.

\section{Acknowledgments}

This work is partly supported by NIAID AI50736. We thank Dr. Stephen H. Clarke for helpful suggestions and consultations.

\section{Literature Cited}

1. Alvarez D, Vollmann EH, von Andrian UH. Mechanisms and consequences of dendritic cell migration. Immunity 2008;29:325-342. [PubMed: 18799141]

2. Khan WN. B cell receptor and BAFF receptor signaling regulation of B cell homeostasis. J Immunol 2009;183:3561-3567. [PubMed: 19726767]

3. Lourenco EV, La Cava A. Cytokines in systemic lupus erythematosus. Curr Mol Med 2009;9:242254. [PubMed: 19355907]

4. Hoffman RW. T cells in the pathogenesis of systemic lupus erythematosus. Clin Immunol 2004;113:413. [PubMed: 15380523]

5. Goodnow CC. Multistep pathogenesis of autoimmune disease. Cell 2007;130:25-35. [PubMed: 17632054]

6. Shlomchik MJ. Sites and stages of autoreactive B cell activation and regulation. Immunity 2008;28:1828. [PubMed: 18199415]

7. Vilen BJ, Rutan JA. The regulation of autoreactive B cells during innate immune responses. Immunol Res 2008;41:295-309. [PubMed: 18704765]

8. Belkaid Y, Oldenhove G. Tuning microenvironments: induction of regulatory T cells by dendritic cells. Immunity 2008;29:362-371. [PubMed: 18799144]

9. Clarke SH. Anti-Sm B cell tolerance and tolerance loss in systemic lupus erythematosus. Immunol Res 2008;41:203-216. [PubMed: 18592142]

10. Liu K, Mohan C. Altered B-cell signaling in lupus. Autoimmun Rev 2009;8:214-218. [PubMed: 18722559]

11. Rescigno M, Lopatin U, Chieppa M. Interactions among dendritic cells, macrophages, and epithelial cells in the gut: implications for immune tolerance. Curr Opin Immunol 2008;20:669-675. [PubMed: 18852045]

12. Cerovic V, McDonald V, Nassar MA, Paulin SM, Macpherson GG, Milling SW. New insights into the roles of dendritic cells in intestinal immunity and tolerance. Int Rev Cell Mol Biol 2009;272:33105. [PubMed: 19121816]

13. Ginhoux F, Tacke F, Angeli V, et al. Langerhans cells arise from monocytes in vivo. Nat Immunol 2006;7:265-273. [PubMed: 16444257]

14. Lahoud MH, Proietto AI, Gartlan KH, et al. Signal regulatory protein molecules are differentially expressed by CD8- dendritic cells. J Immunol 2006;177:372-382. [PubMed: 16785533]

15. Hagnerud S, Manna PP, Cella M, et al. Deficit of CD47 results in a defect of marginal zone dendritic cells, blunted immune response to particulate antigen and impairment of skin dendritic cell migration. J Immunol 2006;176:5772-5778. [PubMed: 16670282]

16. Henri S, Vremec D, Kamath A, et al. The dendritic cell populations of mouse lymph nodes. J Immunol 2001;167:741-748. [PubMed: 11441078]

17. Shortman K, Liu YJ. Mouse and human dendritic cell subtypes. Nat Rev Immunol 2002;2:151-161. [PubMed: 11913066]

18. Leenen PJ, Radosevic K, Voerman JS, et al. Heterogeneity of mouse spleen dendritic cells: in vivo phagocytic activity, expression of macrophage markers, and subpopulation turnover. J Immunol 1998;160:2166-2173. [PubMed: 9498754] 
19. Maldonado-Lopez R, Moser M. Dendritic cell subsets and the regulation of Th1/Th2 responses. Semin Immunol 2001;13:275-282. [PubMed: 11502162]

20. Schnorrer P, Behrens GM, Wilson NS, et al. The dominant role of CD8+ dendritic cells in crosspresentation is not dictated by antigen capture. Proc Natl Acad Sci U S A 2006;103:10729-10734. [PubMed: 16807294]

21. Dudziak D, Kamphorst AO, Heidkamp GF, et al. Differential antigen processing by dendritic cell subsets in vivo. Science 2007;315:107-111. [PubMed: 17204652]

22. Maroof A, Kaye PM. Temporal regulation of interleukin-12p70 (IL-12p70) and IL-12-related cytokines in splenic dendritic cell subsets during Leishmania donovani infection. Infect Immun 2008;76:239-249. [PubMed: 17998312]

23. den Haan JM, Lehar SM, Bevan MJ. CD8(+) but not CD8(-) dendritic cells cross-prime cytotoxic T cells in vivo. J Exp Med 2000;192:1685-1696. [PubMed: 11120766]

24. Yarovinsky F, Kanzler H, Hieny S, Coffman RL, Sher A. Toll-like receptor recognition regulates immunodominance in an antimicrobial CD4+ T cell response. Immunity 2006;25:655-664. [PubMed: 17000122]

25. Lopez-Bravo M, Ardavin C. In vivo induction of immune responses to pathogens by conventional dendritic cells. Immunity 2008;29:343-351. [PubMed: 18799142]

26. Holyst MM, Hill DL, Hoch SO, Hoffman RW. Analysis of human T cell and B cell responses against U small nuclear ribonucleoprotein 70-kd, B, and D polypeptides among patients with systemic lupus erythematosus and mixed connective tissue disease. Arthritis Rheum 1997;40:1493-1503. [PubMed: 9259431]

27. Talken BL, Schafermeyer KR, Bailey CW, Lee DR, Hoffman RW. T cell epitope mapping of the Smith antigen reveals that highly conserved Smith antigen motifs are the dominant target of T cell immunity in systemic lupus erythematosus. J Immunol 2001;167:562-568. [PubMed: 11418695]

28. Talken BL, Bailey CW, Reardon SL, Caldwell CW, Hoffman RW. Structural analysis of TCRalpha and beta chains from human T-Cell clones specific for small nuclear ribonucleoprotein polypeptides Sm-D, Sm-B and U1-70 kDa: TCR complementarity determining region 3 usage appears highly conserved. Scand J Immunol 2001;54:204-210. [PubMed: 11439168]

29. Greidinger EL, Gazitt T, Jaimes KF, Hoffman RW. Human T cell clones specific for heterogeneous nuclear ribonucleoprotein A2 autoantigen from connective tissue disease patients assist in autoantibody production. Arthritis Rheum 2004;50:2216-2222. [PubMed: 15248220]

30. Rajagopalan S, Zordan T, Tsokos GC, Datta SK. Pathogenic anti-DNA autoantibody-inducing T helper cell lines from patients with active lupus nephritis: isolation of CD4-8- T helper cell lines that express the gamma delta T-cell antigen receptor. Proc Natl Acad Sci U S A 1990;87:7020-7024. [PubMed: 2144899]

31. Siegal FP, Kadowaki N, Shodell M, et al. The nature of the principal type 1 interferon-producing cells in human blood. Science 1999;284:1835-1837. [PubMed: 10364556]

32. Rissoan MC, Soumelis V, Kadowaki N, et al. Reciprocal control of T helper cell and dendritic cell differentiation. Science 1999;283:1183-1186. [PubMed: 10024247]

33. Cella M, Jarrossay D, Facchetti F, et al. Plasmacytoid monocytes migrate to inflamed lymph nodes and produce large amounts of type I interferon. Nat Med 1999;5:919-923. [PubMed: 10426316]

34. Grouard G, Rissoan MC, Filgueira L, Durand I, Banchereau J, Liu YJ. The enigmatic plasmacytoid T cells develop into dendritic cells with interleukin (IL)-3 and CD40-ligand. J Exp Med 1997;185:1101-1111. [PubMed: 9091583]

35. O'Doherty U, Peng M, Gezelter S, et al. Human blood contains two subsets of dendritic cells, one immunologically mature and the other immature. Immunology 1994;82:487-493. [PubMed: 7525461]

36. Dzionek A, Inagaki Y, Okawa K, et al. Plasmacytoid dendritic cells: from specific surface markers to specific cellular functions. Hum Immunol 2002;63:1133-1148. [PubMed: 12480257]

37. Nakano H, Yanagita M, Gunn MD. CD11c(+)B220(+)Gr-1(+) cells in mouse lymph nodes and spleen display characteristics of plasmacytoid dendritic cells. J Exp Med 2001;194:1171-1178. [PubMed: 11602645] 
38. O'Keeffe M, Hochrein H, Vremec D, et al. Mouse plasmacytoid cells: long-lived cells, heterogeneous in surface phenotype and function, that differentiate into CD8(+) dendritic cells only after microbial stimulus. J Exp Med 2002;196:1307-1319. [PubMed: 12438422]

39. Comeau MR, Van der Vuurst de Vries AR, Maliszewski CR, Galibert L. CD123bright plasmacytoid predendritic cells: progenitors undergoing cell fate conversion? J Immunol 2002;169:75-83. [PubMed: 12077231]

40. Boonstra A, Asselin-Paturel C, Gilliet M, et al. Flexibility of mouse classical and plasmacytoidderived dendritic cells in directing T helper type 1 and 2 cell development: dependency on antigen dose and differential toll-like receptor ligation. J Exp Med 2003;197:101-109. [PubMed: 12515817]

41. Ahmad-Nejad P, Hacker H, Rutz M, Bauer S, Vabulas RM, Wagner H. Bacterial CpG-DNA and lipopolysaccharides activate Toll-like receptors at distinct cellular compartments. Eur J Immunol 2002;32:1958-1968. [PubMed: 12115616]

42. Hemmi H, Kaisho T, Takeuchi O, et al. Small anti-viral compounds activate immune cells via the TLR7 MyD88-dependent signaling pathway. Nat Immunol 2002;3:196-200. [PubMed: 11812998]

43. Barchet W, Cella M, Colonna M. Plasmacytoid dendritic cells--virus experts of innate immunity. Semin Immunol 2005;17:253-261. [PubMed: 15990333]

44. Diebold SS, Kaisho T, Hemmi H, Akira S, Reis e Sousa C. Innate antiviral responses by means of TLR7-mediated recognition of single-stranded RNA. Science 2004;303:1529-1531. [PubMed: 14976261]

45. Lund JM, Alexopoulou L, Sato A, et al. Recognition of single-stranded RNA viruses by Toll-like receptor 7. Proc Natl Acad Sci U S A 2004;101:5598-5603. [PubMed: 15034168]

46. Krug A, Towarowski A, Britsch S, et al. Toll-like receptor expression reveals CpG DNA as a unique microbial stimulus for plasmacytoid dendritic cells which synergizes with CD40 ligand to induce high amounts of IL-12. Eur J Immunol 2001;31:3026-3037. [PubMed: 11592079]

47. Blomberg S, Eloranta ML, Cederblad B, Nordlin K, Alm GV, Ronnblom L. Presence of cutaneous interferon-alpha producing cells in patients with systemic lupus erythematosus. Lupus 2001;10:484490. [PubMed: 11480846]

48. Farkas L, Beiske K, Lund-Johansen F, Brandtzaeg P, Jahnsen FL. Plasmacytoid dendritic cells (natural interferon- alpha/beta-producing cells) accumulate in cutaneous lupus erythematosus lesions. Am J Pathol 2001;159:237-243. [PubMed: 11438470]

49. Ronnblom L, Alm GV. The natural interferon-alpha producing cells in systemic lupus erythematosus. Hum Immunol 2002;63:1181-1193. [PubMed: 12480262]

50. Tucci M, Quatraro C, Lombardi L, Pellegrino C, Dammacco F, Silvestris F. Glomerular accumulation of plasmacytoid dendritic cells in active lupus nephritis: role of interleukin-18. Arthritis Rheum 2008;58:251-262. [PubMed: 18163476]

51. Rock J, Schneider E, Grun JR, et al. CD303 (BDCA-2) signals in plasmacytoid dendritic cells via a BCR-like signalosome involving Syk, Slp65 and PLCgamma2. Eur J Immunol 2007;37:3564-3575. [PubMed: 18022864]

52. O'Keeffe M, Grumont RJ, Hochrein H, et al. Distinct roles for the NF-kappaB1 and c-Rel transcription factors in the differentiation and survival of plasmacytoid and conventional dendritic cells activated by TLR-9 signals. Blood 2005;106:3457-3464. [PubMed: 16037393]

53. Christensen SR, Kashgarian M, Alexopoulou L, Flavell RA, Akira S, Shlomchik MJ. Toll-like receptor 9 controls anti-DNA autoantibody production in murine lupus. J Exp Med 2005;202:321331. [PubMed: 16027240]

54. Christensen SR, Shupe J, Nickerson K, Kashgarian M, Flavell RA, Shlomchik MJ. Toll-like receptor 7 and TLR9 dictate autoantibody specificity and have opposing inflammatory and regulatory roles in a murine model of lupus. Immunity 2006;25:417-428. [PubMed: 16973389]

55. Wu X, Peng SL. Toll-like receptor 9 signaling protects against murine lupus. Arthritis Rheum 2006;54:336-342. [PubMed: 16385525]

56. Krug A, Uppaluri R, Facchetti F, et al. IFN-producing cells respond to CXCR3 ligands in the presence of CXCL12 and secrete inflammatory chemokines upon activation. J Immunol 2002;169:6079-6083. [PubMed: 12444109] 
57. Vanbervliet B, Bendriss-Vermare N, Massacrier C, et al. The inducible CXCR3 ligands control plasmacytoid dendritic cell responsiveness to the constitutive chemokine stromal cell-derived factor 1 (SDF-1)/CXCL12. J Exp Med 2003;198:823-830. [PubMed: 12953097]

58. Yoneyama H, Matsuno K, Zhang Y, et al. Evidence for recruitment of plasmacytoid dendritic cell precursors to inflamed lymph nodes through high endothelial venules. Int Immunol 2004;16:915928. [PubMed: 15159375]

59. Nicholas MW, Dooley MA, Hogan SL, et al. A novel subset of memory B cells is enriched in autoreactivity and correlates with adverse outcomes in SLE. Clin Immunol 2008;126:189-201. [PubMed: 18077220]

60. Papadimitraki ED, Choulaki C, Koutala E, et al. Expansion of toll-like receptor 9-expressing B cells in active systemic lupus erythematosus: implications for the induction and maintenance of the autoimmune process. Arthritis Rheum 2006;54:3601-3611. [PubMed: 17075805]

61. Ehlers M, Fukuyama H, McGaha TL, Aderem A, Ravetch JV. TLR9/MyD88 signaling is required for class switching to pathogenic IgG2a and 2b autoantibodies in SLE. J Exp Med 2006;203:553561. [PubMed: 16492804]

62. Barrat FJ, Meeker T, Chan JH, Guiducci C, Coffman RL. Treatment of lupus-prone mice with a dual inhibitor of TLR7 and TLR9 leads to reduction of autoantibody production and amelioration of disease symptoms. Eur J Immunol 2007;37:3582-3586. [PubMed: 18034431]

63. Tew JG, Thorbecke GJ, Steinman RM. Dendritic cells in the immune response: characteristics and recommended nomenclature (A report from the Reticuloendothelial Society Committee on Nomenclature). J Reticuloendothel Soc 1982;31:371-380. [PubMed: 6750114]

64. Gonzalez SF, Pitcher LA, Mempel T, Schuerpf F, Carroll MC. B cell acquisition of antigen in vivo. Curr Opin Immunol 2009;21:251-257. [PubMed: 19515546]

65. Hannum LG, Haberman AM, Anderson SM, Shlomchik MJ. Germinal center initiation, variable gene region hypermutation, and mutant $\mathrm{B}$ cell selection without detectable immune complexes on follicular dendritic cells. J Exp Med 2000;192:931-942. [PubMed: 11015435]

66. Tew JG, Wu J, Fakher M, Szakal AK, Qin D. Follicular dendritic cells: beyond the necessity of Tcell help. Trends Immunol 2001;22:361-367. [PubMed: 11429319]

67. Allen CD, Cyster JG. Follicular dendritic cell networks of primary follicles and germinal centers: phenotype and function. Semin Immunol 2008;20:14-25. [PubMed: 18261920]

68. Suzuki K, Grigorova I, Phan TG, Kelly LM, Cyster JG. Visualizing B cell capture of cognate antigen from follicular dendritic cells. J Exp Med 2009;206:1485-1493. [PubMed: 19506051]

69. Yoon SO, Zhang X, Berner P, Blom B, Choi YS. Notch ligands expressed by follicular dendritic cells protect germinal center B cells from apoptosis. J Immunol 2009;183:352-358. [PubMed: 19542446]

70. Baumann I, Kolowos W, Voll RE, et al. Impaired uptake of apoptotic cells into tingible body macrophages in germinal centers of patients with systemic lupus erythematosus. Arthritis Rheum 2002;46:191-201. [PubMed: 11817590]

71. Victoratos P, Kollias G. Induction of autoantibody-mediated spontaneous arthritis critically depends on follicular dendritic cells. Immunity 2009;30:130-142. [PubMed: 19119026]

72. Kranich J, Krautler NJ, Heinen E, et al. Follicular dendritic cells control engulfment of apoptotic bodies by secreting Mfge8. J Exp Med 2008;205:1293-1302. [PubMed: 18490487]

73. Kojima M, Nakamura S, Morishita Y, et al. Reactive follicular hyperplasia in the lymph node lesions from systemic lupus erythematosus patients: a clinicopathological and immunohistological study of 21 cases. Pathol Int 2000;50:304-312. [PubMed: 10849316]

74. Gaipl US, Munoz LE, Grossmayer G, et al. Clearance deficiency and systemic lupus erythematosus (SLE). J Autoimmun 2007;28:114-121. [PubMed: 17368845]

75. Savill J, Dransfield I, Gregory C, Haslett C. A blast from the past: clearance of apoptotic cells regulates immune responses. Nat Rev Immunol 2002;2:965-975. [PubMed: 12461569]

76. Lauber K, Bohn E, Krober SM, et al. Apoptotic cells induce migration of phagocytes via caspase-3mediated release of a lipid attraction signal. Cell 2003;113:717-730. [PubMed: 12809603]

77. Peter C, Waibel M, Radu CG, et al. Migration to apoptotic "find-me" signals is mediated via the phagocyte receptor G2A. J Biol Chem 2008;283:5296-5305. [PubMed: 18089568]

78. Sheriff A, Gaipl US, Voll RE, Kalden JR, Herrmann M. Apoptosis and systemic lupus erythematosus. Rheum Dis Clin North Am 2004;30:505-527. viii-ix. [PubMed: 15261339] 
79. Ronnblom L, Pascual V. The innate immune system in SLE: type I interferons and dendritic cells. Lupus 2008;17:394-399. [PubMed: 18490415]

80. Hoffmann PR, Kench JA, Vondracek A, et al. Interaction between phosphatidylserine and the phosphatidylserine receptor inhibits immune responses in vivo. J Immunol 2005;174:1393-1404. [PubMed: 15661897]

81. Ren Y, Xie Y, Jiang G, et al. Apoptotic cells protect mice against lipopolysaccharide-induced shock. J Immunol 2008;180:4978-4985. [PubMed: 18354223]

82. Sen P, Wallet MA, Yi Z, et al. Apoptotic cells induce Mer tyrosine kinase-dependent blockade of NF-kappaB activation in dendritic cells. Blood 2007;109:653-660. [PubMed: 17008547]

83. Wallet MA, Sen P, Flores RR, et al. MerTK is required for apoptotic cell-induced T cell tolerance. J Exp Med 2008;205:219-232. [PubMed: 18195070]

84. Chen X, Doffek K, Sugg SL, Shilyansky J. Phosphatidylserine regulates the maturation of human dendritic cells. J Immunol 2004;173:2985-2994. [PubMed: 15322157]

85. Amoura Z, Koutouzov S, Piette JC. The role of nucleosomes in lupus. Curr Opin Rheumatol 2000;12:369-373. [PubMed: 10990171]

86. Willingham SB, Allen IC, Bergstralh DT, et al. NLRP3 (NALP3, Cryopyrin) facilitates in vivo caspase-1 activation, necrosis, and HMGB1 release via inflammasome-dependent and -independent pathways. J Immunol 2009;183:2008-2015. [PubMed: 19587006]

87. Urbonaviciute V, Furnrohr BG, Meister S, et al. Induction of inflammatory and immune responses by HMGB1-nucleosome complexes: implications for the pathogenesis of SLE. J Exp Med 2008;205:3007-3018. [PubMed: 19064698]

88. Scaffidi P, Misteli T, Bianchi ME. Release of chromatin protein HMGB1 by necrotic cells triggers inflammation. Nature 2002;418:191-195. [PubMed: 12110890]

89. Berkun Y, Verbovetski I, Ben-Ami A, et al. Altered dendritic cells with tolerizing phenotype in patients with systemic lupus erythematosus. Eur J Immunol 2008;38:2896-2904. [PubMed: 18958888]

90. Liu G, Wang J, Park YJ, et al. High mobility group protein-1 inhibits phagocytosis of apoptotic neutrophils through binding to phosphatidylserine. J Immunol 2008;181:4240-4246. [PubMed: 18768881]

91. Iyoda T, Shimoyama S, Liu K, et al. The CD8+ dendritic cell subset selectively endocytoses dying cells in culture and in vivo. J Exp Med 2002;195:1289-1302. [PubMed: 12021309]

92. Schulz O, Reis e Sousa C. Cross-presentation of cell-associated antigens by CD8alpha+ dendritic cells is attributable to their ability to internalize dead cells. Immunology 2002;107:183-189. [PubMed: 12383197]

93. Sancho D, Mourao-Sa D, Joffre OP, et al. Tumor therapy in mice via antigen targeting to a novel, DC-restricted C-type lectin. J Clin Invest 2008;118:2098-2110. [PubMed: 18497879]

94. Schwaeble W, Schafer MK, Petry F, et al. Follicular dendritic cells, interdigitating cells, and cells of the monocyte-macrophage lineage are the C1q-producing sources in the spleen. Identification of specific cell types by in situ hybridization and immunohistochemical analysis. J Immunol 1995;155:4971-4978. [PubMed: 7594503]

95. Ogden CA, deCathelineau A, Hoffmann PR, et al. C1q and mannose binding lectin engagement of cell surface calreticulin and CD91 initiates macropinocytosis and uptake of apoptotic cells. J Exp Med 2001;194:781-795. [PubMed: 11560994]

96. Lu JH, Teh BK, Wang L, et al. The classical and regulatory functions of C1q in immunity and autoimmunity. Cell Mol Immunol 2008;5:9-21. [PubMed: 18318990]

97. Seitz HM, Camenisch TD, Lemke G, Earp HS, Matsushima GK. Macrophages and dendritic cells use different Axl/Mertk/Tyro3 receptors in clearance of apoptotic cells. J Immunol 2007;178:56355642. [PubMed: 17442946]

98. Behrens EM, Gadue P, Gong SY, Garrett S, Stein PL, Cohen PL. The mer receptor tyrosine kinase: expression and function suggest a role in innate immunity. Eur J Immunol 2003;33:2160-2167. [PubMed: 12884290]

99. Wu Y, Singh S, Georgescu MM, Birge RB. A role for Mer tyrosine kinase in alphavbeta5 integrinmediated phagocytosis of apoptotic cells. J Cell Sci 2005;118:539-553. [PubMed: 15673687] 
100. Mahajan NP, Earp HS. An SH2 domain-dependent, phosphotyrosine-independent interaction between Vav1 and the Mer receptor tyrosine kinase: a mechanism for localizing guanine nucleotideexchange factor action. J Biol Chem 2003;278:42596-42603. [PubMed: 12920122]

101. Hanayama R, Tanaka M, Miyasaka K, et al. Autoimmune disease and impaired uptake of apoptotic cells in MFG-E8-deficient mice. Science 2004;304:1147-1150. [PubMed: 15155946]

102. Anderson HA, Maylock CA, Williams JA, Paweletz CP, Shu H, Shacter E. Serum-derived protein $\mathrm{S}$ binds to phosphatidylserine and stimulates the phagocytosis of apoptotic cells. Nat Immunol 2003;4:87-91. [PubMed: 12447359]

103. Asano K, Miwa M, Miwa K, et al. Masking of phosphatidylserine inhibits apoptotic cell engulfment and induces autoantibody production in mice. J Exp Med 2004;200:459-467. [PubMed: 15302904]

104. Akakura S, Singh S, Spataro M, et al. The opsonin MFG-E8 is a ligand for the alphavbeta5 integrin and triggers DOCK180-dependent Rac1 activation for the phagocytosis of apoptotic cells. Exp Cell Res 2004;292:403-416. [PubMed: 14697347]

105. Rothlin CV, Ghosh S, Zuniga EI, Oldstone MB, Lemke G. TAM receptors are pleiotropic inhibitors of the innate immune response. Cell 2007;131:1124-1136. [PubMed: 18083102]

106. Todt JC, Hu B, Curtis JL. The scavenger receptor SR-A I/II (CD204) signals via the receptor tyrosine kinase Mertk during apoptotic cell uptake by murine macrophages. J Leukoc Biol 2008;84:510 518. [PubMed: 18511575]

107. Scott RS, McMahon EJ, Pop SM, et al. Phagocytosis and clearance of apoptotic cells is mediated by MER. Nature 2001;411:207-211. [PubMed: 11346799]

108. Lu Q, Lemke G. Homeostatic regulation of the immune system by receptor tyrosine kinases of the Tyro 3 family. Science 2001;293:306-311. [PubMed: 11452127]

109. Cohen PL, Caricchio R, Abraham V, et al. Delayed apoptotic cell clearance and lupus-like autoimmunity in mice lacking the c-mer membrane tyrosine kinase. J Exp Med 2002;196:135-140. [PubMed: 12093878]

110. N AG, Bensinger SJ, Hong C, et al. Apoptotic cells promote their own clearance and immune tolerance through activation of the nuclear receptor LXR. Immunity 2009;31:245-258. [PubMed: 19646905]

111. Nagata K, Ohashi K, Nakano T, et al. Identification of the product of growth arrest-specific gene 6 as a common ligand for Axl, Sky, and Mer receptor tyrosine kinases. J Biol Chem 1996;271:3002230027. [PubMed: 8939948]

112. Tjwa M, Bellido-Martin L, Lin Y, et al. Gas6 promotes inflammation by enhancing interactions between endothelial cells, platelets, and leukocytes. Blood 2008;111:4096-4105. [PubMed: 18156494]

113. Guermazi S, Regnault V, Gorgi Y, Ayed K, Lecompte T, Dellagi K. Further evidence for the presence of anti-protein $\mathrm{S}$ autoantibodies in patients with systemic lupus erythematosus. Blood Coagul Fibrinolysis 2000;11:491-498. [PubMed: 10937810]

114. Saller F, Brisset AC, Tchaikovski SN, et al. Generation and phenotypic analysis of protein S-deficient mice. Blood 2009;114:2307-2314. [PubMed: 19567881]

115. Song KS, Park YS, Kim HK. Prevalence of anti-protein S antibodies in patients with systemic lupus erythematosus. Arthritis Rheum 2000;43:557-560. [PubMed: 10728748]

116. Uehara H, Shacter E. Auto-oxidation and oligomerization of protein $\mathrm{S}$ on the apoptotic cell surface is required for Mer tyrosine kinase-mediated phagocytosis of apoptotic cells. J Immunol 2008;180:2522-2530. [PubMed: 18250462]

117. Stitt TN, Conn G, Gore M, et al. The anticoagulation factor protein S and its relative, Gas6, are ligands for the Tyro 3/Axl family of receptor tyrosine kinases. Cell 1995;80:661-670. [PubMed: 7867073]

118. Lucas M, Stuart LM, Zhang A, et al. Requirements for apoptotic cell contact in regulation of macrophage responses. J Immunol 2006;177:4047-4054. [PubMed: 16951368]

119. Belz GT, Vremec D, Febbraio M, et al. CD36 is differentially expressed by CD8+ splenic dendritic cells but is not required for cross-presentation in vivo. J Immunol 2002;168:6066-6070. [PubMed: 12055215]

120. Workman CJ, Wang Y, El Kasmi KC, et al. LAG-3 regulates plasmacytoid dendritic cell homeostasis. J Immunol 2009;182:1885-1891. [PubMed: 19201841] 
121. Hooks JJ, Moutsopoulos HM, Geis SA, Stahl NI, Decker JL, Notkins AL. Immune interferon in the circulation of patients with autoimmune disease. N Engl J Med 1979;301:5-8. [PubMed: 449915]

122. Kalkner KM, Ronnblom L, Karlsson Parra AK, Bengtsson M, Olsson Y, Oberg K. Antibodies against double-stranded DNA and development of polymyositis during treatment with interferon. Qjm 1998;91:393-399. [PubMed: 9709457]

123. Ronnblom LE, Alm GV, Oberg KE. Autoimmunity after alpha-interferon therapy for malignant carcinoid tumors. Ann Intern Med 1991;115:178-183. [PubMed: 2058872]

124. Theofilopoulos AN, Baccala R, Beutler B, Kono DH. Type I interferons (alpha/beta) in immunity and autoimmunity. Annu Rev Immunol 2005;23:307-336. [PubMed: 15771573]

125. Kyogoku C, Tsuchiya N. A compass that points to lupus: genetic studies on type I interferon pathway. Genes Immun 2007;8:445-455. [PubMed: 17581625]

126. Sharif MN, Sosic D, Rothlin CV, et al. Twist mediates suppression of inflammation by type I IFNs and Axl. J Exp Med 2006;203:1891-1901. [PubMed: 16831897]

127. Lemke G, Rothlin CV. Immunobiology of the TAM receptors. Nat Rev Immunol 2008;8:327-336. [PubMed: 18421305]

128. Scutera S, Fraone T, Musso T, et al. Survival and migration of human dendritic cells are regulated by an IFN-alpha-inducible Axl/Gas6 pathway. J Immunol 2009;183:3004-3013. [PubMed: 19657094]

129. Vallin H, Perers A, Alm GV, Ronnblom L. Anti-double-stranded DNA antibodies and immunostimulatory plasmid DNA in combination mimic the endogenous IFN-alpha inducer in systemic lupus erythematosus. J Immunol 1999;163:6306-6313. [PubMed: 10570325]

130. Ronnblom L, Alm GV. A pivotal role for the natural interferon alpha-producing cells (plasmacytoid dendritic cells) in the pathogenesis of lupus. J Exp Med 2001;194:F59-F63. [PubMed: 11748288]

131. Hasegawa K, Hayashi T. Synthetic CpG oligodeoxynucleotides accelerate the development of lupus nephritis during preactive phase in NZB $\times$ NZWF1 mice. Lupus 2003;12:838-845. [PubMed: 14667100]

132. Adam C, Thoua Y, Ronco P, Verroust P, Tovey M, Morel-Maroger L. The effect of exogenous interferon: acceleration of autoimmune and renal diseases in (NZB/W) F1 mice. Clin Exp Immunol 1980;40:373-382. [PubMed: 6160000]

133. Braun D, Geraldes P, Demengeot J. Type I Interferon controls the onset and severity of autoimmune manifestations in lpr mice. J Autoimmun 2003;20:15-25. [PubMed: 12604309]

134. Jorgensen TN, Roper E, Thurman JM, Marrack P, Kotzin BL. Type I interferon signaling is involved in the spontaneous development of lupus-like disease in B6.Nba2 and (B6.Nba2 $\times$ NZW)F(1) mice. Genes Immun 2007;8:653-662. [PubMed: 17882225]

135. Nacionales DC, Kelly-Scumpia KM, Lee PY, et al. Deficiency of the type I interferon receptor protects mice from experimental lupus. Arthritis Rheum 2007;56:3770-3783. [PubMed: 17968932]

136. Santiago-Raber ML, Baccala R, Haraldsson KM, et al. Type-I interferon receptor deficiency reduces lupus-like disease in NZB mice. J Exp Med 2003;197:777-788. [PubMed: 12642605]

137. Baechler EC, Batliwalla FM, Karypis G, et al. Interferon-inducible gene expression signature in peripheral blood cells of patients with severe lupus. Proc Natl Acad Sci U S A 2003;100:2610 2615. [PubMed: 12604793]

138. Sigurdsson S, Nordmark G, Goring HH, et al. Polymorphisms in the tyrosine kinase 2 and interferon regulatory factor 5 genes are associated with systemic lupus erythematosus. Am J Hum Genet 2005;76:528-537. [PubMed: 15657875]

139. Hellquist A, Jarvinen TM, Koskenmies S, et al. Evidence for genetic association and interaction between the TYK2 and IRF5 genes in systemic lupus erythematosus. J Rheumatol 2009;36:16311638. [PubMed: 19567624]

140. Decker T, Stockinger S, Karaghiosoff M, Muller M, Kovarik P. IFNs and STATs in innate immunity to microorganisms. J Clin Invest 2002;109:1271-1277. [PubMed: 12021240]

141. Honda K, Taniguchi T. IRFs: master regulators of signalling by Toll-like receptors and cytosolic pattern-recognition receptors. Nat Rev Immunol 2006;6:644-658. [PubMed: 16932750]

142. Ho V, McLean A, Terry S. Severe systemic lupus erythematosus induced by antiviral treatment for hepatitis C. J Clin Rheumatol 2008;14:166-168. [PubMed: 18525437] 
143. Bennett L, Palucka AK, Arce E, et al. Interferon and granulopoiesis signatures in systemic lupus erythematosus blood. J Exp Med 2003;197:711-723. [PubMed: 12642603]

144. Preble OT, Black RJ, Friedman RM, Klippel JH, Vilcek J. Systemic lupus erythematosus: presence in human serum of an unusual acid-labile leukocyte interferon. Science 1982;216:429-431. [PubMed: 6176024]

145. Blanco P, Palucka AK, Gill M, Pascual V, Banchereau J. Induction of dendritic cell differentiation by IFN-alpha in systemic lupus erythematosus. Science 2001;294:1540-1543. [PubMed: 11711679]

146. Bave U, Magnusson M, Eloranta ML, Perers A, Alm GV, Ronnblom L. Fc gamma RIIa is expressed on natural IFN-alpha-producing cells (plasmacytoid dendritic cells) and is required for the IFNalpha production induced by apoptotic cells combined with lupus IgG. J Immunol 2003;171:32963302. [PubMed: 12960360]

147. Eloranta ML, Lovgren T, Finke D, et al. Regulation of the interferon-alpha production induced by RNA-containing immune complexes in plasmacytoid dendritic cells. Arthritis Rheum 2009;60:2418-2427. [PubMed: 19644885]

148. Poeck H, Wagner M, Battiany J, et al. Plasmacytoid dendritic cells, antigen, and CpG-C license human B cells for plasma cell differentiation and immunoglobulin production in the absence of Tcell help. Blood 2004;103:3058-3064. [PubMed: 15070685]

149. Jego G, Palucka AK, Blanck JP, Chalouni C, Pascual V, Banchereau J. Plasmacytoid dendritic cells induce plasma cell differentiation through type I interferon and interleukin 6. Immunity 2003;19:225-234. [PubMed: 12932356]

150. Fransen JH, Hilbrands LB, Ruben J, et al. Mouse dendritic cells matured by ingestion of apoptotic blebs induce T cells to produce interleukin-17. Arthritis Rheum 2009;60:2304-2313. [PubMed: 19644874]

151. Le Bon A, Schiavoni G, D'Agostino G, Gresser I, Belardelli F, Tough DF. Type i interferons potently enhance humoral immunity and can promote isotype switching by stimulating dendritic cells in vivo. Immunity 2001;14:461-470. [PubMed: 11336691]

152. Meller S, Winterberg F, Gilliet M, et al. Ultraviolet radiation-induced injury, chemokines, and leukocyte recruitment: An amplification cycle triggering cutaneous lupus erythematosus. Arthritis Rheum 2005;52:1504-1516. [PubMed: 15880822]

153. Lafyatis R, York M. Innate immunity and inflammation in systemic sclerosis. Curr Opin Rheumatol. 2009

154. Marshak-Rothstein A. Toll-like receptors in systemic autoimmune disease. Nat Rev Immunol 2006;6:823-835. [PubMed: 17063184]

155. Richez C, Yasuda K, Watkins AA, et al. TLR4 ligands induce IFN-alpha production by mouse conventional dendritic cells and human monocytes after IFN-beta priming. J Immunol 2009;182:820-828. [PubMed: 19124725]

156. Sakaguchi S, Negishi H, Asagiri M, et al. Essential role of IRF-3 in lipopolysaccharide-induced interferon-beta gene expression and endotoxin shock. Biochem Biophys Res Commun 2003;306:860-866. [PubMed: 12821121]

157. Akahoshi M, Nakashima H, Sadanaga A, et al. Promoter polymorphisms in the IRF3 gene confer protection against systemic lupus erythematosus. Lupus 2008;17:568-574. [PubMed: 18539711]

158. Jacob CO, Zhu J, Armstrong DL, et al. Identification of IRAK1 as a risk gene with critical role in the pathogenesis of systemic lupus erythematosus. Proc Natl Acad Sci U S A 2009;106:6256-6261. [PubMed: 19329491]

159. Zhu J, Liu X, Xie C, et al. T cell hyperactivity in lupus as a consequence of hyperstimulatory antigenpresenting cells. J Clin Invest 2005;115:1869-1878. [PubMed: 15951839]

160. Jorgensen TN, Gubbels MR, Kotzin BL. Links between type I interferons and the genetic basis of disease in mouse lupus. Autoimmunity 2003;36:491-502. [PubMed: 14984026]

161. Choubey D, Panchanathan R. Interferon-inducible Ifi200-family genes in systemic lupus erythematosus. Immunol Lett 2008;119:32-41. [PubMed: 18598717]

162. Rozzo SJ, Allard JD, Choubey D, et al. Evidence for an interferon-inducible gene, Ifi202, in the susceptibility to systemic lupus. Immunity 2001;15:435-443. [PubMed: 11567633] 
163. Vyse TJ, Kotzin BL. Genetic susceptibility to systemic lupus erythematosus. Annu Rev Immunol 1998;16:261-292. [PubMed: 9597131]

164. Wakeland EK, Liu K, Graham RR, Behrens TW. Delineating the genetic basis of systemic lupus erythematosus. Immunity 2001;15:397-408. [PubMed: 11567630]

165. Jacobi AM, Zhang J, Mackay M, Aranow C, Diamond B. Phenotypic characterization of autoreactive B cells--checkpoints of B cell tolerance in patients with systemic lupus erythematosus. PLoS One 2009;4:e5776. [PubMed: 19488401]

166. Burckstummer T, Baumann C, Bluml S, et al. An orthogonal proteomic-genomic screen identifies AIM2 as a cytoplasmic DNA sensor for the inflammasome. Nat Immunol 2009;10:266-272. [PubMed: 19158679]

167. Fernandes-Alnemri T, Yu JW, Datta P, Wu J, Alnemri ES. AIM2 activates the inflammasome and cell death in response to cytoplasmic DNA. Nature 2009;458:509-513. [PubMed: 19158676]

168. Hornung V, Ablasser A, Charrel-Dennis M, et al. AIM2 recognizes cytosolic dsDNA and forms a caspase-1-activating inflammasome with ASC. Nature 2009;458:514-518. [PubMed: 19158675]

169. Roberts TL, Idris A, Dunn JA, et al. HIN-200 proteins regulate caspase activation in response to foreign cytoplasmic DNA. Science 2009;323:1057-1060. [PubMed: 19131592]

170. Stranges PB, Watson J, Cooper CJ, et al. Elimination of antigen-presenting cells and autoreactive T cells by Fas contributes to prevention of autoimmunity. Immunity 2007;26:629-641. [PubMed: 17509906]

171. Nopora A, Brocker T. Bcl-2 controls dendritic cell longevity in vivo. J Immunol 2002;169:30063014. [PubMed: 12218115]

172. Chen M, Wang YH, Wang Y, et al. Dendritic cell apoptosis in the maintenance of immune tolerance. Science 2006;311:1160-1164. [PubMed: 16497935]

173. Guo Z, Zhang M, Tang H, Cao X. Fas signal links innate and adaptive immunity by promoting dendritic-cell secretion of CC and CXC chemokines. Blood 2005;106:2033-2041. [PubMed: 15941911]

174. Matzinger P, Guerder S. Does T-cell tolerance require a dedicated antigen-presenting cell? Nature 1989;338:74-76. [PubMed: 2783992]

175. Walker LS, Abbas AK. The enemy within: keeping self-reactive T cells at bay in the periphery. Nat Rev Immunol 2002;2:11-19. [PubMed: 11908514]

176. Zal T, Volkmann A, Stockinger B. Mechanisms of tolerance induction in major histocompatibility complex class II-restricted T cells specific for a blood-borne self-antigen. J Exp Med 1994;180:2089-2099. [PubMed: 7964486]

177. Steinman RM, Turley S, Mellman I, Inaba K. The induction of tolerance by dendritic cells that have captured apoptotic cells. J Exp Med 2000;191:411-416. [PubMed: 10662786]

178. Steinbrink K, Mahnke K, Grabbe S, Enk AH, Jonuleit H. Myeloid dendritic cell: From sentinel of immunity to key player of peripheral tolerance? Hum Immunol 2009;70:289-293. [PubMed: 19217922]

179. Balazs M, Martin F, Zhou T, Kearney J. Blood dendritic cells interact with splenic marginal zone B cells to initiate T-independent immune responses. Immunity 2002;17:341-352. [PubMed: 12354386]

180. Craxton A, Magaletti D, Ryan EJ, Clark EA. Macrophage- and dendritic cell--dependent regulation of human B-cell proliferation requires the TNF family ligand BAFF. Blood 2003;101:4464-4471. [PubMed: 12531790]

181. Kilmon MA, Rutan JA, Clarke SH, Vilen BJ. Low-affinity, Smith antigen-specific B cells are tolerized by dendritic cells and macrophages. J Immunol 2005;175:37-41. [PubMed: 15972629]

182. Kilmon MA, Wagner NJ, Garland AL, et al. Macrophages prevent the differentiation of autoreactive B cells by secreting CD40 ligand and IL-6. Blood. 2007

183. Gilbert MR, Carnathan DG, Cogswell PC, Lin L, Baldwin AS Jr, Vilen BJ. Dendritic cells from lupus-prone mice are defective in repressing immunoglobulin secretion. J Immunol 2007;178:4803-4810. [PubMed: 17404261] 


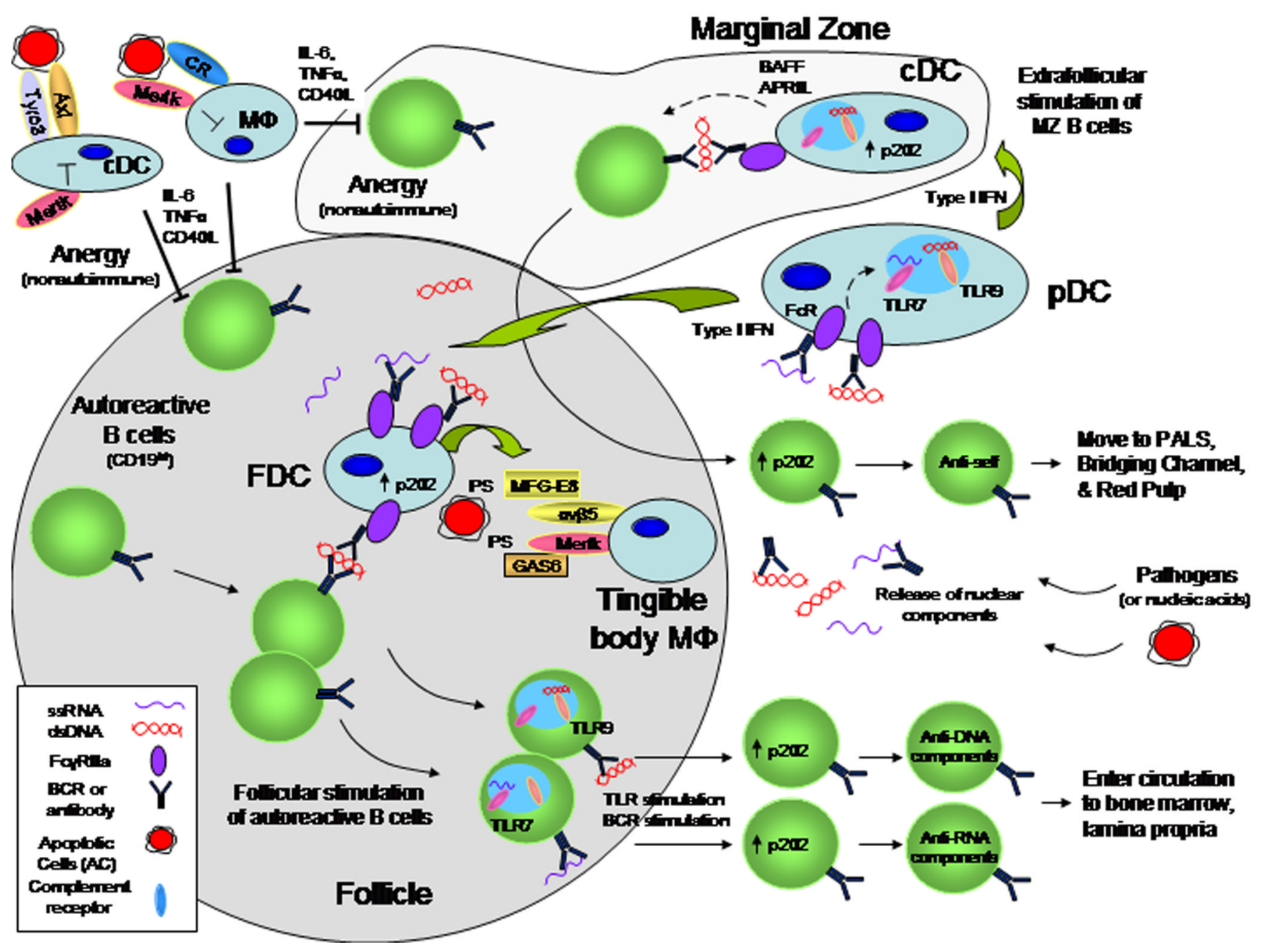

Figure 1.

General model for potential roles of DCs in the regulation of autoreactive B cells in secondary lymphoid tissues. Normal immune homeostasis regulates autoreactive B cells. Plausible mechanisms that inhibit autoreactive B cells include B cell anergy due to a block in BCR signaling or to repression of chronically stimulated follicular B cells from the local production of IL-6, TNF $\alpha$ and CD40L by DCs and macrophages or marginal zone (MZ) B cells by macrophages. ACs may suppress DCs and macrophages from becoming hyperactive. Defects in clearing ACs by DCs and macrophages increase self antigens available to B cells and releases checks in DC (or macrophage) activity or survival. In addition, nucleic material from pathogens or ACs maybe endocytosed or they may form antigen-antibody immune complexes (IC) that bind Fc receptors (FcR) on several cell types and are internalized into endosomes. TLR7 and TLR9 sense RNA or DNA complex components and trigger IFNI (type I interferon) secretion particularly by pDC. High levels of IFNI production is associated with increased p202 that may affect several cells including B cells and FDC in germinal centers as well as cDC. The activated FDC have been shown to secrete MFG-E8 which binds PS on ACs and $\alpha \mathrm{v} \beta 5$ integrin on tingible-body macrophages to facilitate ingestion. Similarly, GAS6 binds both PS on ACs and Mertk on macrophages and cooperates with $\alpha v \beta 5$ to facilitate efficient engulfment of dying cells. In addition, complement $\mathrm{C} 1 \mathrm{q}$ deficiency results in impaired clearance by macrophages via CD91 and autoantibody formation. The lack of MFG-E8, Mertk or C1q results in autoantibody formation in animal models. The FDCs can also provide immune-complexed self 
antigens to autoreactive B cells. In the presence of IFNI, B cells will upregulate TLR7 or TLR9 and sufficient BCR and TLR stimulation may break tolerance of autoreactive follicular B cells. These follicular B cells migrate out into the circulation to become memory B cells or antibodysecreting cells. In the MZ, cDC may also become activated by IFNI and nuclear material which promotes cytokine production. These activated cDC may sufficiently stimulate BCR-, BAFF-, and TLR-mediated activation of MZ B cells that then migrate through the follicle to become antibody-secreting cells in the bridging channels or red pulp. 
Table 1

Characterization of different dendritic cell subtypes.

\begin{tabular}{|c|c|c|c|c|}
\hline & $\begin{array}{l}\text { Primary } \\
\text { Localization }\end{array}$ & $\begin{array}{l}\text { Human } \\
\text { Markers }\end{array}$ & Murine Markers & $\begin{array}{l}\text { Relevance } \\
\text { to SLE }\end{array}$ \\
\hline $\begin{array}{l}\text { Conventional DC's } \\
\text { (cDC) }\end{array}$ & $\begin{array}{l}\text { Mucosal tissues } \\
\text { and skin }\end{array}$ & CD11chi, MHCII & $\begin{array}{l}\text { Resident: CD } 8 \alpha^{+} \text {, } \\
\text { CD } 11 c^{+}, \mathrm{CD} 11 \mathrm{~b}^{-} \text {, } \\
\text { CD } 205^{+} \\
\text {Migratory: CD } 8 \alpha^{-} \text {, } \\
\text { CD } 11 \mathrm{c}^{+}, \mathrm{CD} 11 \mathrm{~b}^{+/-} \text {, } \\
\text { CD205 }\end{array}$ & $\begin{array}{l}\text { Induce specific } \\
\text { adaptive immune } \\
\text { responses. } \\
\text { Maintain self } \\
\text { tolerance }\end{array}$ \\
\hline $\begin{array}{l}\text { Plasmacytoid DC's } \\
(\mathrm{pDC})\end{array}$ & $\begin{array}{l}\text { Blood, lymph } \\
\text { nodes, spleen, } \\
\text { bone marrow, } \\
\text { liver }\end{array}$ & $\begin{array}{l}\mathrm{CD}^{+}, \mathrm{CD} 11 \mathrm{c}^{-}, \\
\mathrm{CD}^{+} 6^{+}, \mathrm{CD} 45 \mathrm{RA}^{+}, \\
\mathrm{CD} 123^{+}, \mathrm{ILT}^{-}, \\
\mathrm{ILT}^{+}\end{array}$ & $\begin{array}{l}\mathrm{CD}^{+}, \mathrm{CD} 11 \mathrm{c}^{\mathrm{lo}}, \\
\mathrm{CD} 123^{-}, \mathrm{B} 220^{+}, \\
\mathrm{Gr}-1^{+}\end{array}$ & $\begin{array}{l}\text { Produce type } 1 \\
\text { interferon. protect } \\
\text { against pathogens. }\end{array}$ \\
\hline $\begin{array}{l}\text { Follicular DC's } \\
\text { (FDC) }\end{array}$ & $\begin{array}{l}\text { Germinal centers } \\
\text { of secondary } \\
\text { lymph nodes }\end{array}$ & FC $\gamma$ RIIIa & $\begin{array}{l}\text { BP-3+. CD } 21 / 35^{+}, \\
\text {FC } \gamma \text { RIIIb }^{+/-}\end{array}$ & $\begin{array}{l}\text { Retain immune } \\
\text { complexes and } \\
\text { activate B cells }\end{array}$ \\
\hline
\end{tabular}

